\title{
WestVirginiaUniversity
}

THE RESEARCH REPOSITORY @ WVU

West Virginia Agricultural and Forestry Experiment

Davis College of Agriculture, Natural Resources

Station Bulletins

And Design

$1-1-1990$

\section{Growth, yield and fruit quality of 'delicious' apple strains}

Tara A. Baugher

Follow this and additional works at: https://researchrepository.wvu.edu/ wv_agricultural_and_forestry_experiment_station_bulletins

\section{Digital Commons Citation}

Baugher, Tara A., "Growth, yield and fruit quality of 'delicious' apple strains" (1990). West Virginia Agricultural and Forestry Experiment Station Bulletins. 702.

https://researchrepository.wvu.edu/wv_agricultural_and_forestry_experiment_station_bulletins/596 @ WVU. It has been accepted for inclusion in West Virginia Agricultural and Forestry Experiment Station Bulletins by an authorized administrator of The Research Repository @ WVU. For more information, please contact ian.harmon@mail.wvu.edu. 


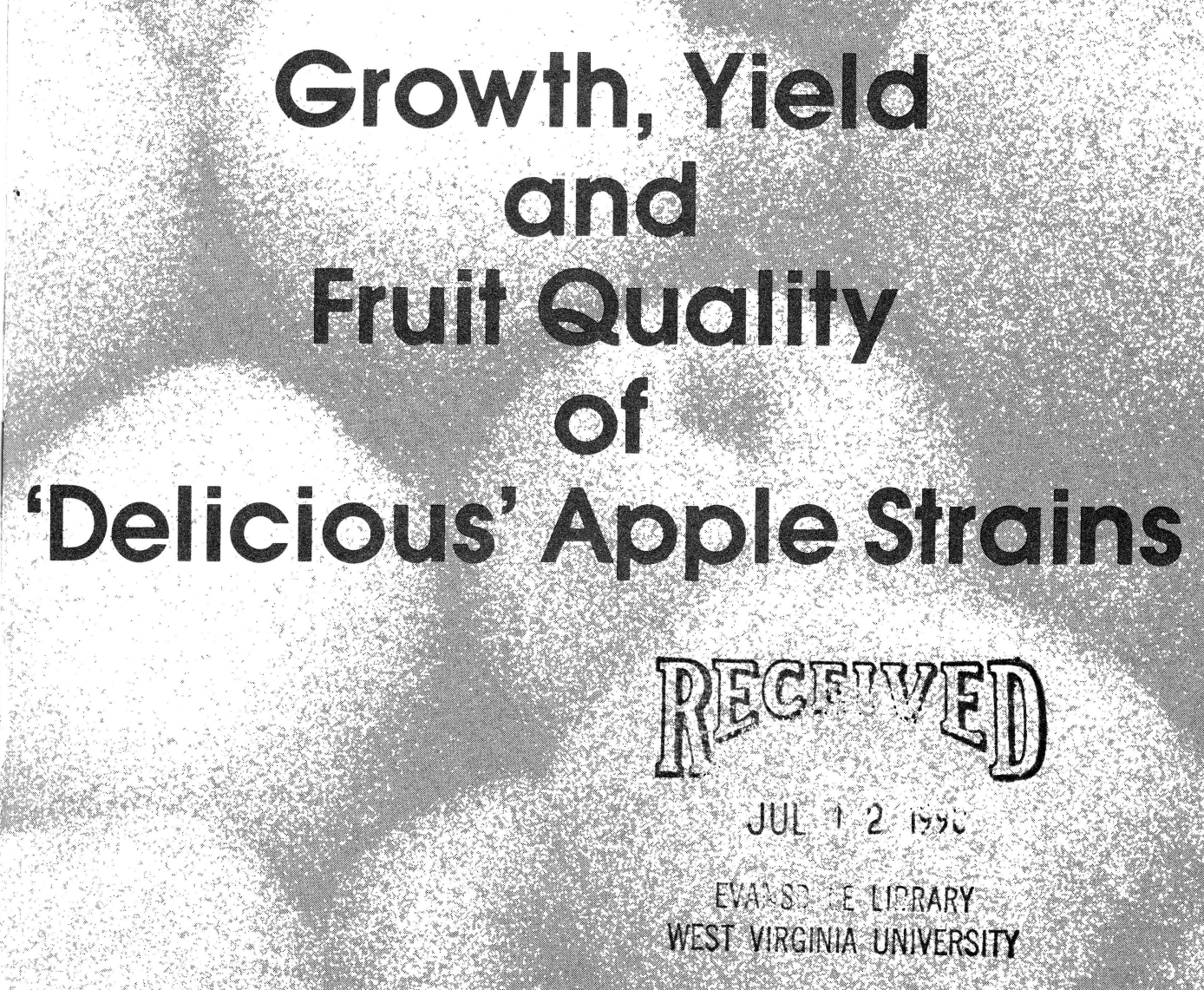

West Virginia Agriculturat and Forestry Experiment Station Sig 7 , El H $7 d 2$ S T VIR G INIA U N IV E R S I T Y Aril.90
$C .2$ 
Authors

Tara A. Baugher is extension specialist, horticulture and associate professor of horticulture; Suman Singha is professor of horticulture; Edwin C. Townsend is professor of statistics and Morris Ingle is professor of horticulture, all in the College of Agriculture and Forestry, West Virginia University

\title{
Acknowledgements
}

The authors gratefully acknowledge the assistance of:

Mervyn C. D'Souza, David W. Leach, Sandra I. Walter, Satish Bhatia, James H. Locke, Kenneth F. Davis, Troy L. Hollis, James L. Locke, Dennis L. Magaha, and Mathew P. Ware.

The following generously contributed trees for the study: Adams County Nursery, Aspers, PA Bountiful Ridge Nursery, Princess Anne, MD Carlton Nursery, Dayton, OR Columbia Basin Nursery, Quincy, WA $C$ and $O$ Nursery, Wenatchee, WA Contra Costa Nursery, Brentwood. CA Bruner Hare, Long Creek, SC Hilltop Orchards and Nurseries, Hartford, MI MayNursery, Yakima, WA

Stark Brothers Nurseries, Louisiana, MO Van Well Nursery, Wenatchee, WA

\author{
West Virginia University \\ Agricultural and Forestry Experiment Station \\ College of Agriculture and Forestry \\ Robert H. Maxwell, Director \\ Morgantown
}




\section{Summary}

Thirty-four currently available strains of 'Delicious' apple were compared in a planting established in 1981 at the West Virginia University Experiment Farm in Kearneysville, WV. Trunk cross-sectional area was measured at the beginning of each season, and measurements of yield and fruit color, size, shape and quality were made during the first four cropping years (1985-1988). Strains that ranked high in attributes considered important for fresh market production under West Virginia growing conditions were 'Scarlett Spur', 'Cascade Spur', 'Ace', 'Oregon Spur II', 'UltraRed', 'Nured Royal', 'Silver Spur', 'UltraStripe' and 'Redchief' (Campbell). Selecting from among these top performing strains involves decisions regarding specific climatic conditions, management schemes and market requirements. 
Blank Page in Original Bulletin 


\section{Contents}

Introduction

Materials and Methods

Results and Discussion

Color 5

Tree Size and Productivity

Fruit Size, Shape and Quality

Overall Acceptability

Literature Cited

Appendices 
Blank Page in Origianl Bulletin 


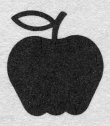

\title{
Growth, Yield and Fruit Quality of 'Delicious' Apple Strains
}

\author{
Tara A. Baugher, Suman Singha, \\ Edwin C. Townsend and Morris Ingle
}

\section{Introduction}

'Delicious' is the major apple cultivar grown in West Virginia and the world. Twenty-eight percent of the apples grown in the state and $37 \%$ of the apples grown in the world are 'Delicious' (Brueggen et al., 1988).

The original 'Delicious' apple, discovered in 1879 (Fisher and Ketchie, 1989), has virtually been replaced by strains of markedly improved color. Over 100 red strains or mutations of 'Delicious' have been identified. In studies where strain color has been compared, either by consumer acceptance panel or colorimeter techniques, significant differences have been identified (Crassweller et al., 1984; Dennis, 1987; Fisher and Ketchie, 1989; Olsen and Ketchie, 1978). Since color development is strongly influenced by climatic conditions, it is important to establish separate trials in each apple growing region (Fisher and Ketchie, 1989; Ketchie et al., 1978; Olsen and Ketchie, 1978).

Strains of 'Delicious' are also selected for compact growth habit and increased productivity. Strains with the non-spur growth habit are being replaced by spur type strains. The most recent West Virginia Fruit Tree Survey (Brueggen et al., 1988) shows that 38\% of the state's 'Delicious' are spur types. The productivity of 'Delicious' is low compared to other cultivars, and while some studies have shown no increase in yields with spur type strains (Lord et al., 1979), others have demonstrated increased yield efficiencies (Dennis, 1981; Ferree et al., 
1982; Ketchie, 1986). Differences in consistency of production have also been reported (Ferree et al., 1982). Characterizing strains as spur types or non-spurs can be misleading as, the degree of "spuriness" can vary. Other methods of defining growth habit include visual ratings (Crassweller and Hollander, 1988) and number of spurs per meter (Ketchie, 1984).

Additional considerations in selecting strains of 'Delicious' include fruit size, shape, date of maturity and quality. Some studies have shown that fruit on spur type strains tend to be typier than on nonspurs (Lord, 1982; Meheriuk et al., 1973), but most research has shown minimal differences (Ketchie, 1986). Distinctions in fruit quality and maturity have been difficult to ascertain due to varying climatic conditions, nutrition and cultural practices. Greener flesh and lower soluble solids have been reported for spur type strains compared to non-spurs, but it is unclear whether the data indicate differences in fruit maturity or reduced dessert quality (Ingle, 1972, 1989; Olsen and Ketchie, 1978).

Planting intentions indicated in fruit tree surveys suggest that 'Delicious' will continue to be a dominant fresh market apple cultivar. With decreased use of growth regulators and increased market competition, it is imperative that growers plant only strains with the right combination of characteristics for a given microclimate, management scheme and market. The major objectives of this study were to compare fruit color, tree growth, fruit size and length/diameter (L/D) ratio, and fruit quality of recently introduced 'Delicious' strains under West Virginia growing conditions, using locally recommended management practices. New strains of 'Delicious' have been continually introduced, and strain evaluation is an on-going process. 


\section{Materials and Methods}

Thirty-four currently available strains of 'Delicious' apple were planted in 1981 and 1982 at the West Virginia University Experiment Farm, Kearneysville. Plots were arranged in a randomized block design, with two five tree replicates separated by 'Golden Delicious' pollinizers. Tree spacing was $4.9 \mathrm{~m}$ by $6.1 \mathrm{~m}$ for a density of 336 trees per hectare.

Major characteristics of the strains are presented in Table 1. 'Starkrimson', 'Topred', and 'Red Prince', strains commonly planted in West Virginia, were included as standards for comparison. The remaining strains had not been evaluated under West Virginia growing conditions. The majority of the strains were on M. 7a rootstock, and other rootstocks were substituted only when the requested rootstock was unavailable. Trunk caliper of the trees was $16 \mathrm{~mm}$ at planting.

The soil at the test site is a Hagerstown silt loam, a common orchard soil in the state. The site was prepared according to local Extension recommendations. Trees were planted with a commercial tree planter, with bud unions set at 2.5 to $5.0 \mathrm{~cm}$ above the soil line. Kentucky-31 fescue was planted in the row middles, and herbicides were applied annually to the tree rows. Fertilizers and pesticides were applied according to Extension Integrated Orchard Management recommendations. Trees were pruned and trained to the Heinicke central leader system (Heinicke, 1974). Carbaryl was applied as a chemical thinner at $10 \mathrm{~mm}$ average fruit size in 1985-1988.

Trunk cross-sectional area (TCSA) $20 \mathrm{~cm}$ above the soil line was determined each spring before active growth began. Yield per tree and per $\mathrm{cm}^{2}$ TCSA were determined in each of the first four cropping years (1985-1988). Ten fruit per replicate were randomly sampled at 145-150 days after full bloom (DAFB) in each year for quality evaluations, including color ratings (by consumer panel instructed to visually rate overall color on a 1 to 10 scale), soluble solids (with a hand-held refractometer), firmness (with an Effegi penetrometer), starch index (Priest and Lougheed, 1981), diameter and L/D ratio. The date of harvesting samples in each year was determined to be within the optimum range for all strains. In agreement with previous research that has indicated insignificant differences in maturity due to strain variation, all strains matured at a similar rate. Data were subjected to analysis of variance, and means were separated by least significant difference (LSD). 


\section{Table 1. \\ Basic characteristics of 'Delicious' strains at the WVU Experiment Farm, Kearneysville.}

(Trees planted 1981 unless otherwise indicated.)

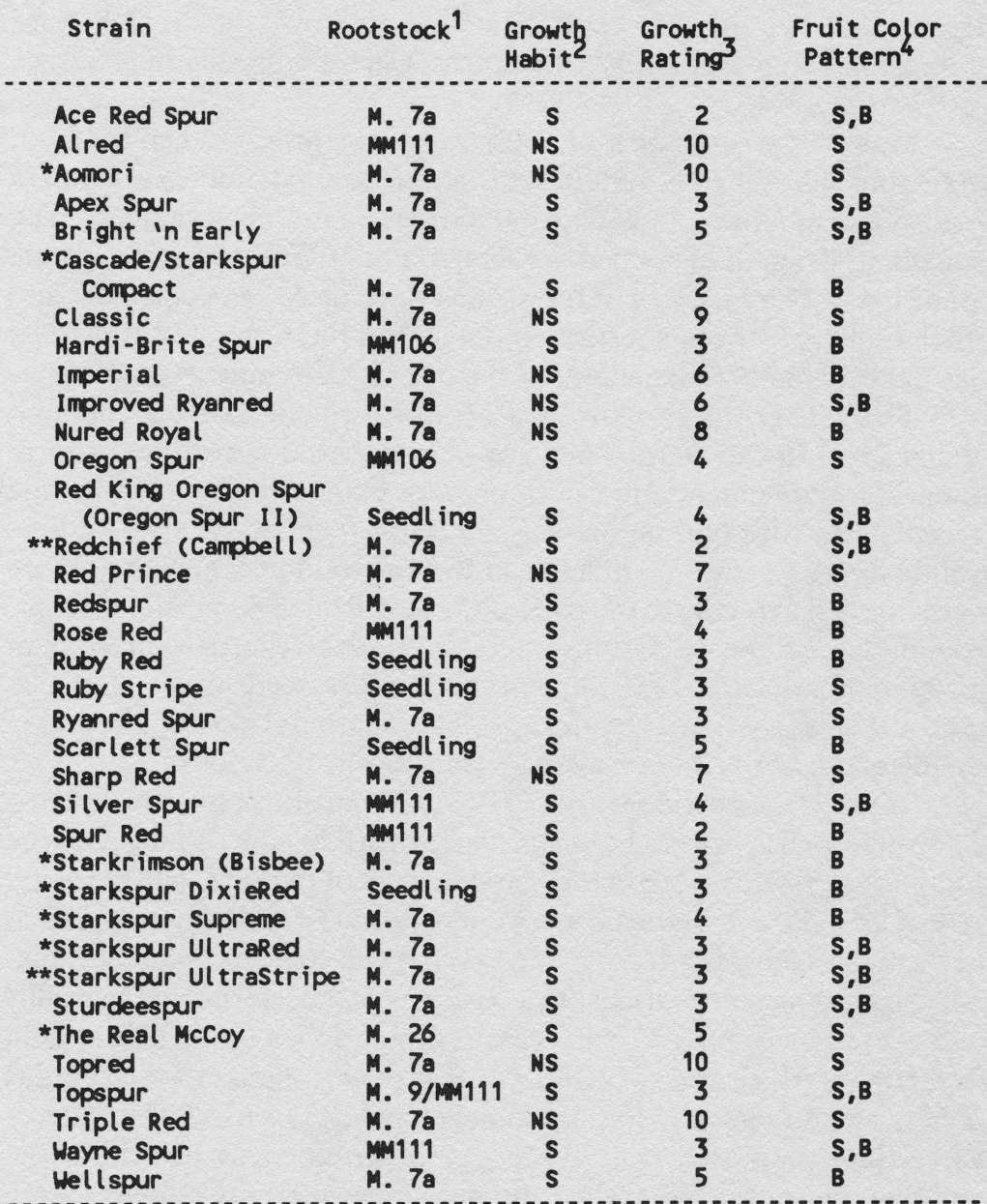

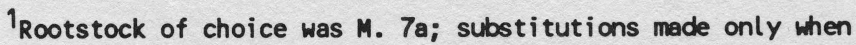
requested rootstock was unavailable.

${ }^{2} S$ = spur type; $N S=$ nonspur.

$3_{B}=$ blushed; $S=$ striped; $S, B=$ striped early turning to blush at harvest.

4 Vigor rated visually on a scale of $1-10$, with 1 being most heavily spurred and/or most compact. $1-5=$ spur types; $6-10=$ nonspurs.

*planted in 1982.

**planted in 1983 and included for color comparisons only. 


\section{Results and Discussion}

In the discussion that follows, all strains were compared except where statistical analysis showed an influence of the rootstock on the scion. The rootstock effects which should be considered when interpreting the data are as follows:

TCSA - Trees on seedling were larger than those on M. 7a; trees of the one strain on M. 9/MM111 were smaller than all other combinations.

Cumulative Yield - Yields of strains on MM106 were greater than yields on all other rootstocks; yields of strains on MM111 were greater than those on seedling. Cumulative yield efficiencies of strains on MM111, MM106 and M.7a were higher than strains on seedling.

Soluble Solids - Trees on M. 26 and M. 9/MM111 had higher soluble solids than trees on MM106, MM111, or seedling; trees on M. $7 \mathrm{a}$ had higher soluble solids than those on seedling.

Influences of planting year existed only for TCSA and yield. For brevity, four-year means are represented in the figures included in the text, and one-year means are shown in the appendices.

\section{Color}

Strains with four-year color means greater than 6.5 received high color ratings in all years (Figure 1; Appendix A). Strains with four-year means less than 6.5 were variable or were consistently rated low. Based on statistical analysis of color ratings 'UltraStripe' had the most desirable color and 'Alred' the least. Coefficients of variation (an indication of how variable the ratings were among years, i.e. a low value indicates greater consistency) revealed that the ratings for some strains were more consistent than others. For example, 'Hardi-Brite Spur' and 'Real McCoy' were consistently rated as low coloring strains whereas 'UltraStripe'and 'Scarlett Spur' were consistently rated high coloring strains. Other studies conducted in this planting indicated that color ratings at 145 days after full bloom were positively correlated to earliness of color and to colorimeter measurements (Singha et al., 1989, 1990). Color ratings were influenced by color pattern, with striped and blushed combinations rated significantly higher than striped apples, and blushed apples rated intermediate $(p=0.05)$. Spur-type growth habit was not correlated with high color ratings, which is in agreement with other reports (Dayton, 1964). 


\section{Tree Size and Productivity}

Apple tree size is highly correlated with TCSA (Westwood and Roberts, 1970). Based on TCSA in this study (Figure 2; Appendix B), the largest trees were 'Topred', 'Aomori' and 'Classic'and the smallest were 'Topspur'. All smaller trees were spur types, and all of the larger trees were non-spur. Spur density (number of spurs per meter) was determined for the strains on M. 7a and reported in 1990 (Warrington et al., 1990). Spur strains, for example 'Sturdeespur', generally had spur densities greater than 20 per meter. Spur densities for 'Sturdeespur', 'Redchief (Campbell)', 'UltraStripe', 'Redspur', and 'Ace', were 39, 38, 36, 33 and 33 per meter, respectively. Spur densities of $15,16,18$, and 18 were found for 'Nured Royal', 'Sharp Red', 'Topred', and 'Aomori', respectively.

Strains with more than $50 \mathrm{~kg}$ cumulative yield per tree (Figure 3, Appendix 3) included 'Wayne Spur', 'Silver Spur', 'Imperial', and 'Cascade Spur' (strains on MM106 excluded due to a rootstock effect). Those with less than $20 \mathrm{~kg}$ included 'Bright 'n Early', 'Triple Red', 'Sharp Red', 'Aomori', 'Rose Red' and 'UltraRed' (strains on seedling excluded due to a rootstock effect). Coefficients of variation indicated that 'Wayne Spur' produced the most consistent yields. The most precocious strains also had the highest cumulative yields. Spring frost reduced the crop of all strains in 1987. Five days of cloudy weather two weeks after bloom reduced fruit set in 1988. The influence was greater on some strains than on others. Of the strains on $\mathrm{M}$. 7a rootstock, cumulative yield efficiency (Figure 4) was $1 \mathrm{~kg}$ per $\mathrm{cm}^{2}$ or higher for 'Ace', 'Cascade Spur', 'Sturdeespur', 'Imperial', and 'Apex'. As reported previously (Warrington et al., 1989), spur density was positively correlated with yield efficiency $(\mathrm{p}=0.05)$.

\section{Fruit Size, Shape and Quality}

Mean fruit diameter, across all strains for the four-year period, was $7.9 \mathrm{~cm}$, and mean L/D ratio was 0.86 (Appendix C). Strains with the largest mean diameters were 'Oregon Spur', 'Silver Spur', and 'Imperial', and those with the smallest diameters were 'Ruby Red' and 'Triple Red' (Figure 5). 'Supreme' was the typiest of the strains, and 'Ryanred' was the least typey (Figure 5). Although differences in L/D ratio were small, spur type growth habit was positively correlated with typiness $(\mathrm{p}=0.05)$.

Mean fruit maturity indices, for all strains over four years, were as follows: firmness - $14.5 \mathrm{lb}$; soluble solids - $13.9 \%$; and starch index - 4.6 (Appendix D). Strains with four-year starch means above the minimum suggested for shipping (a rating of 5) were 'Ultrared', 'Cas- 
cade Spur', 'Sturdeespur', 'Imperial', 'Starkrimson', 'Redspur' and 'Real McCoy'. Based on starch, none of the strains were over-mature when harvested (Figure 6). Four-year firmness means were generally below the minimum suggested for shipping $(15 \mathrm{lb})$, probably because the trees were young and most had a light crop load. Those which were at or above the minimum firmness for shipping included 'Nured Royal', 'Classic', 'Supreme', 'Topspur', 'Topred', and 'Aomori' (Figure 7). All soluble solids means were above the $11.5 \%$ level recommended for shipping (Figure 6). As suggested by investigators from other regions, we were unable to determine sequence of ripening from soluble solids, starch and firmness, either as separate indices or combined. Nonspur growth habit was correlated with high soluble solids and spur-type growth habit with low soluble solids $(p=0.05)$. Sensory evaluations of flavor and crispness were conducted on some of the strains in the test block in 1987, and the results varied depending upon whether the evaluation was conducted at harvest or 60 days after harvest (Crassweller and Hollander, 1988).

\section{Overall Acceptability}

Principal characteristics of the 34 strains in the Kearneysville planting are presented in Figure 7. The level of importance of each characteristic will vary among growers, depending on individual marketing and management schemes. For instance, if color alone is a high priority for a particular market, 'Scarlett Spur' is a leading choice. On the other hand, if equal importance is placed on color and productivity, 'Cascade Spur' and 'Ace' are better options. If major concerns are color and L/D ratio, 'Scarlett Spur' and 'Oregon Spur II' are the two leading selections. Differences in maturity are not distinctive. 


\section{Figure 1. \\ Mean consumer panel color ratings of fruit of 'Delicious' strains harvested 1985-1988.}

Panelists were asked to visually rate overall color (including intensity, percentage of red surface area and uniformity among apples) on a scale of 1 to 10 , with 1 representing poor color and 10 representing excellent color.

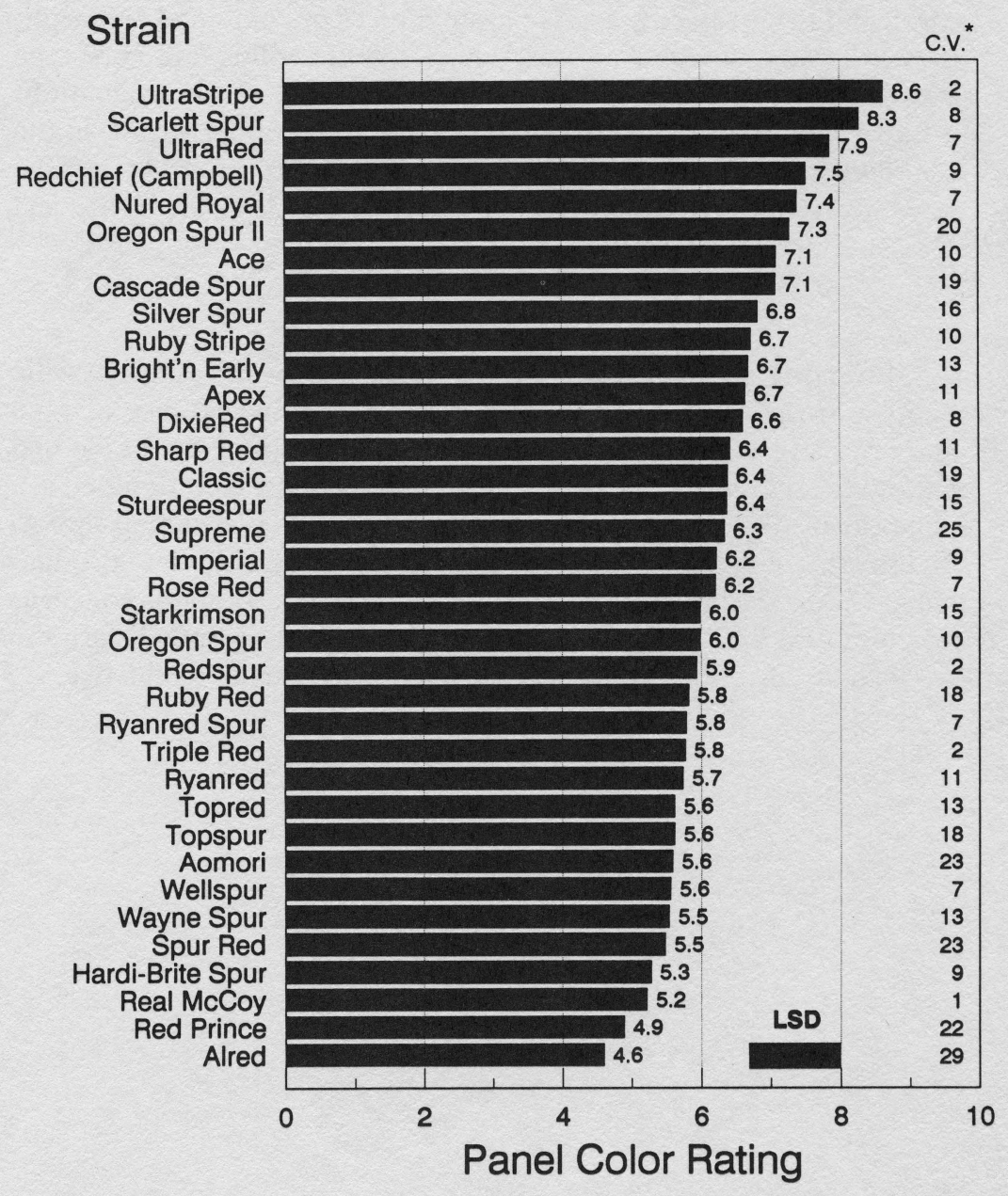

${ }^{*} \mathrm{C} . V .=$ coefficient of annual variation 


\section{Figure 2. \\ Mean cumulative trunk cross-sectional areas of 'Delicious' strains, 1982-1988.}

\section{Strain}

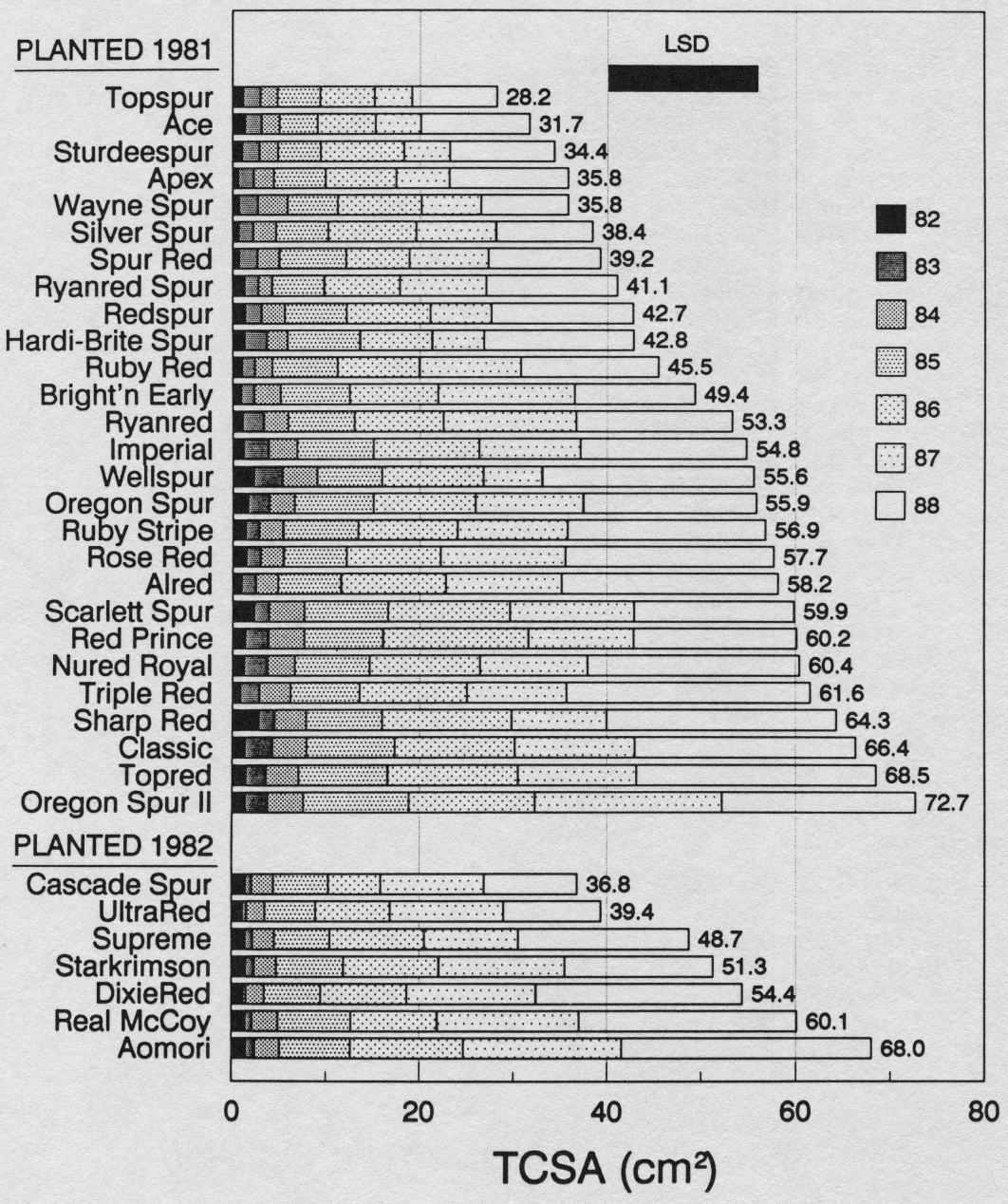




\section{Figure 3. \\ Mean cumulative yields of 'Delicious' strains 1985-1988.}

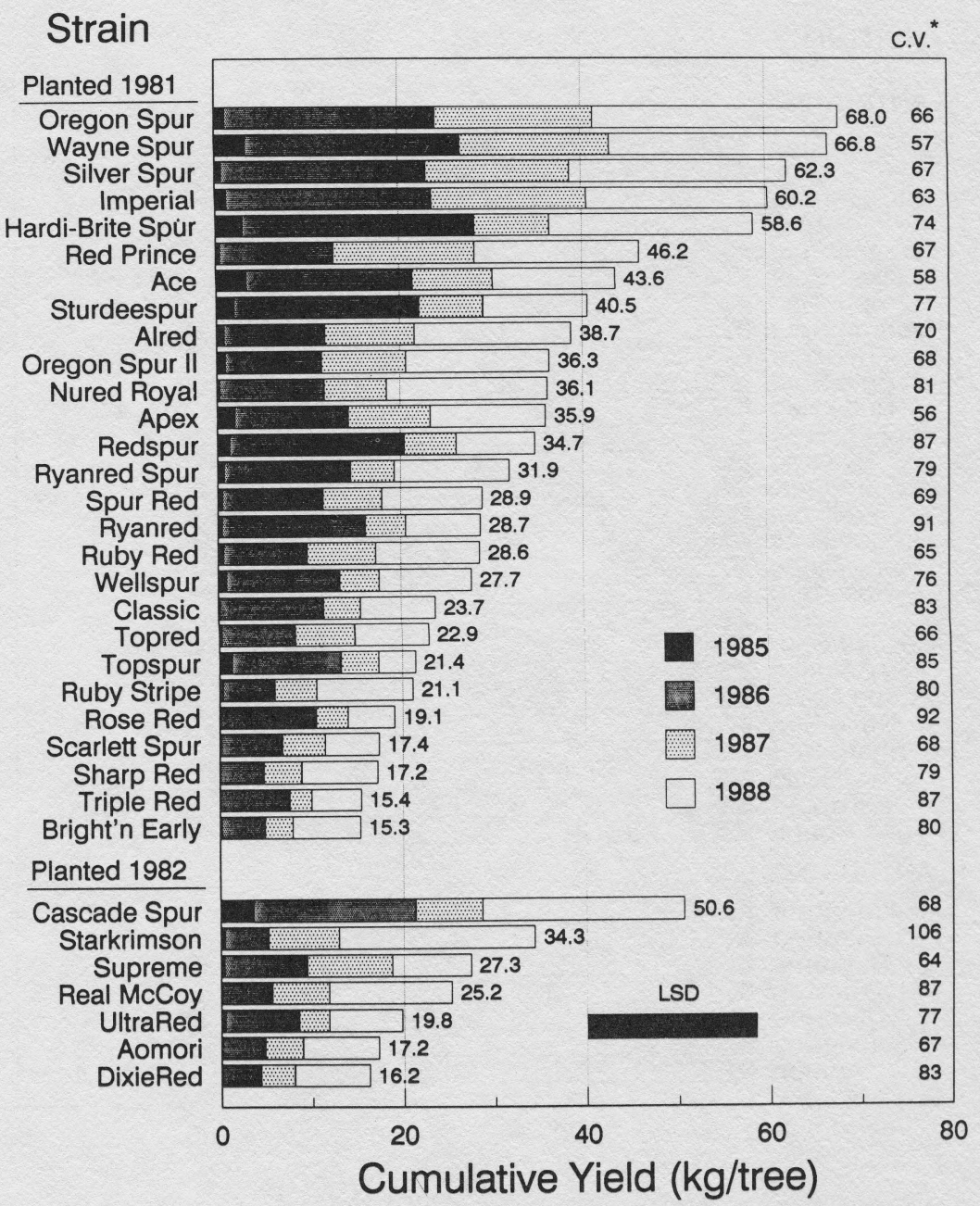

${ }^{*} \mathrm{C} . \mathrm{V} .=$ coefficient of annual variation 
Figure 4.

Mean cumulative yield efficiencies and consumer panel color ratings of 'Delicious' strains on M.7a rootstock 1985- 1988.

Panel Color Rating (1-10 scale)

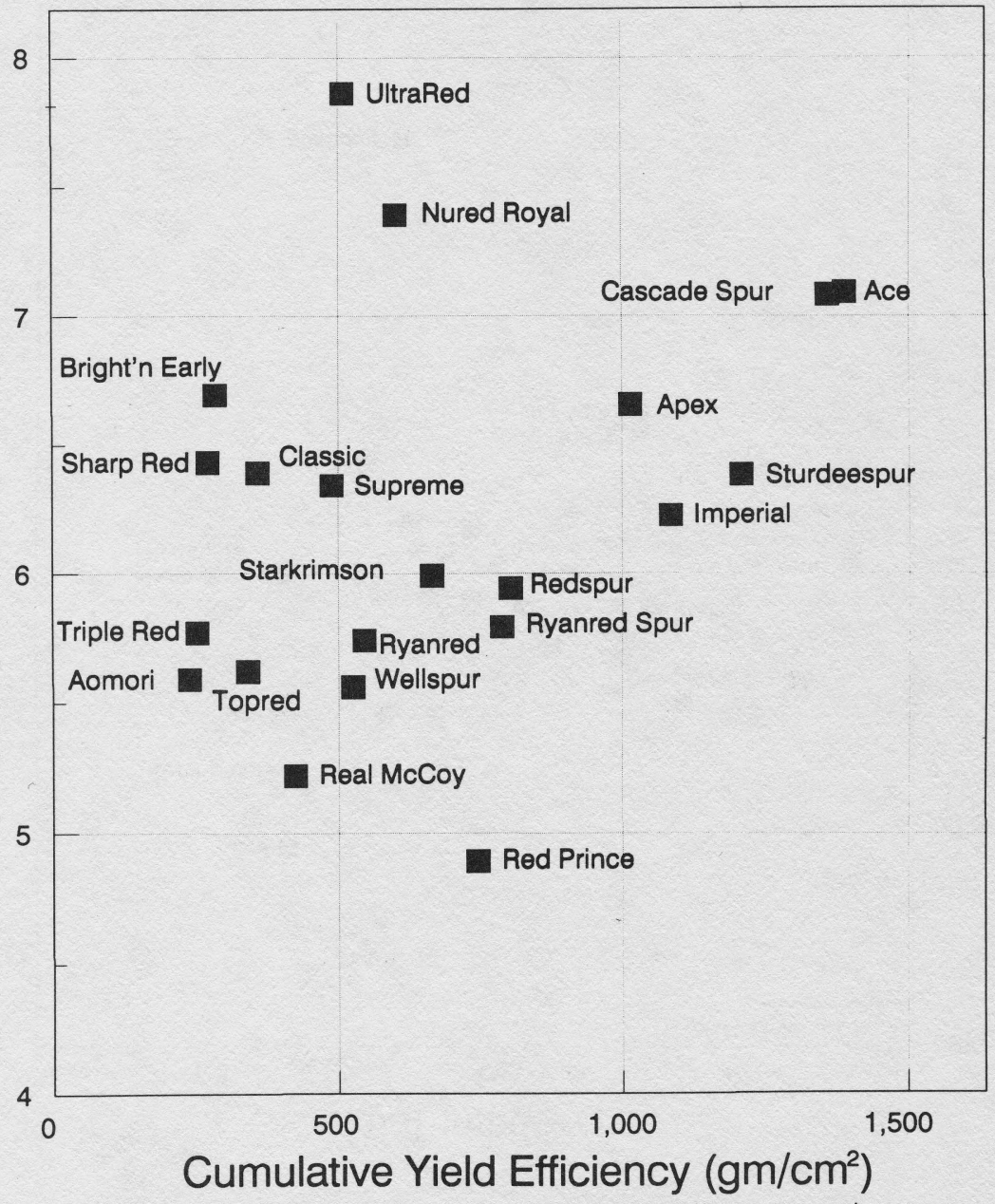




\section{Figure 5.}

\section{Mean diameters and length/diameter ratios of fruit of 'Delicious' strains 1985-1988.}

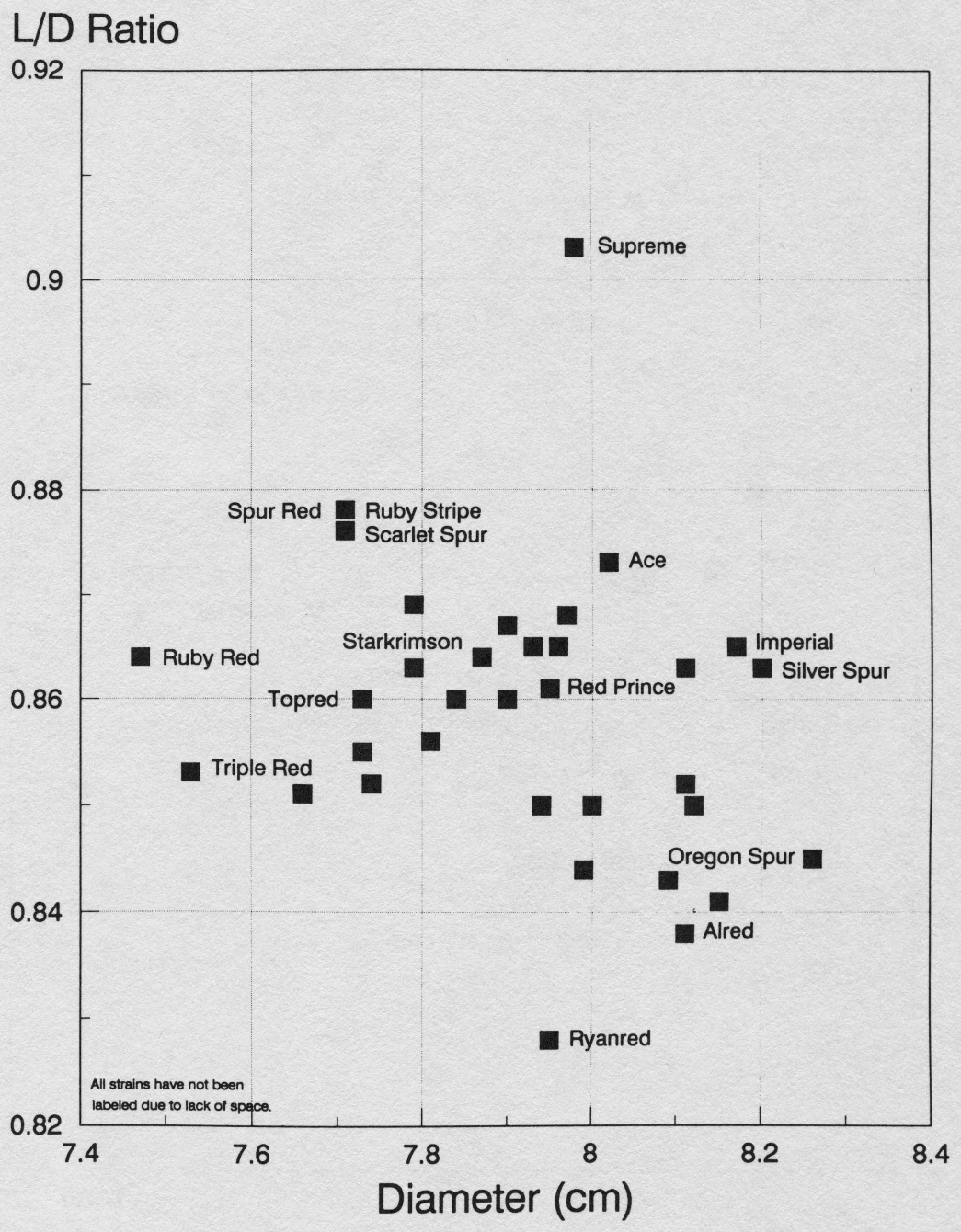




\section{Figure 6. \\ Mean soluble solids and starch indices of fruit of 'Delicious' strains 1985-1988.}

Starch Index

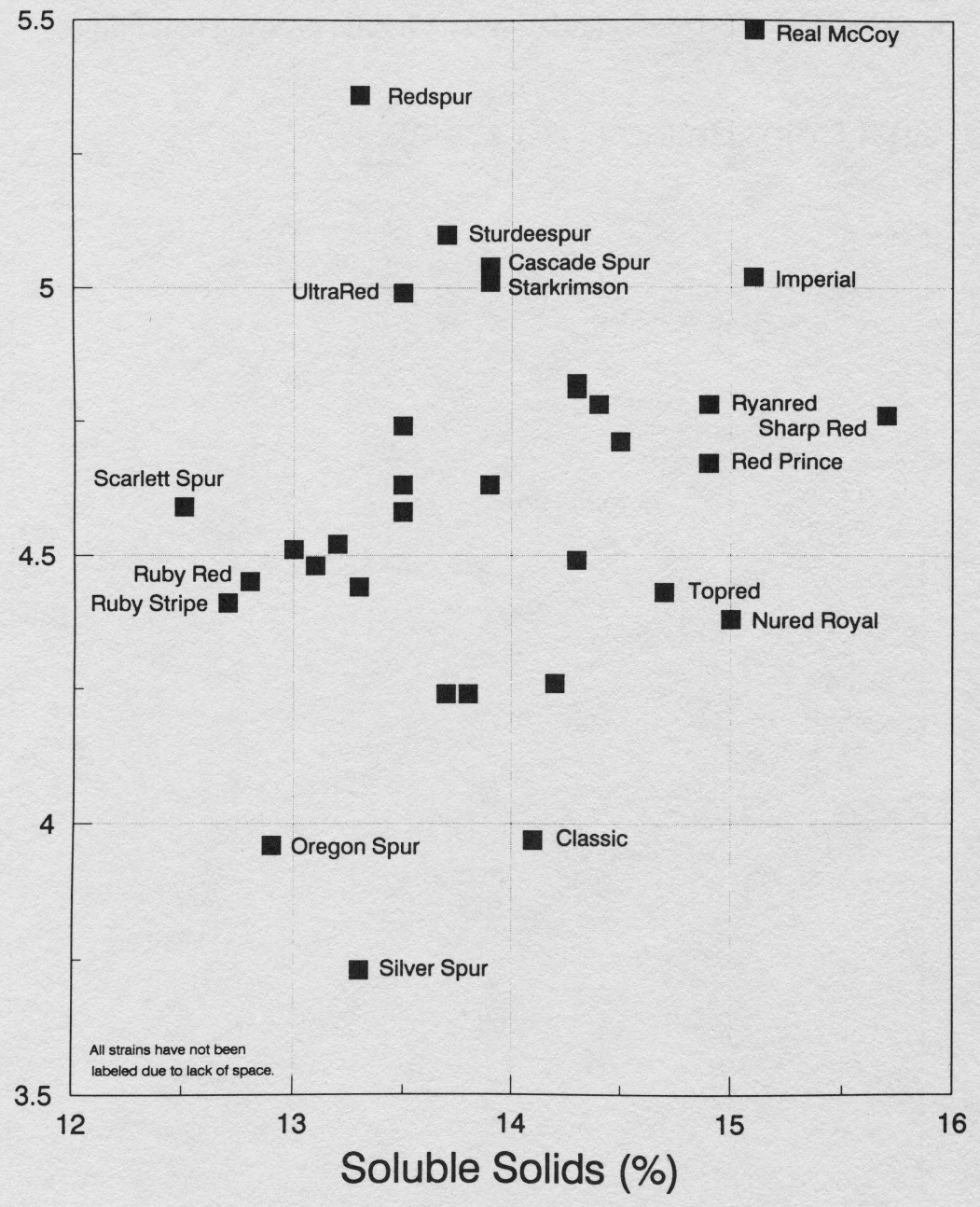




\section{Figure 7. \\ Mean cumulative yield efficiencies and consumer panel color ratings of 'Delicious' strains.}

Symbols indicate which strains met minimum standards for firmness and/or were most typey (based on 1985-1988 means). Unshaded area of figure shows strains with the greatest potential - based on one or more characteristics - under West Virginia growing conditions.

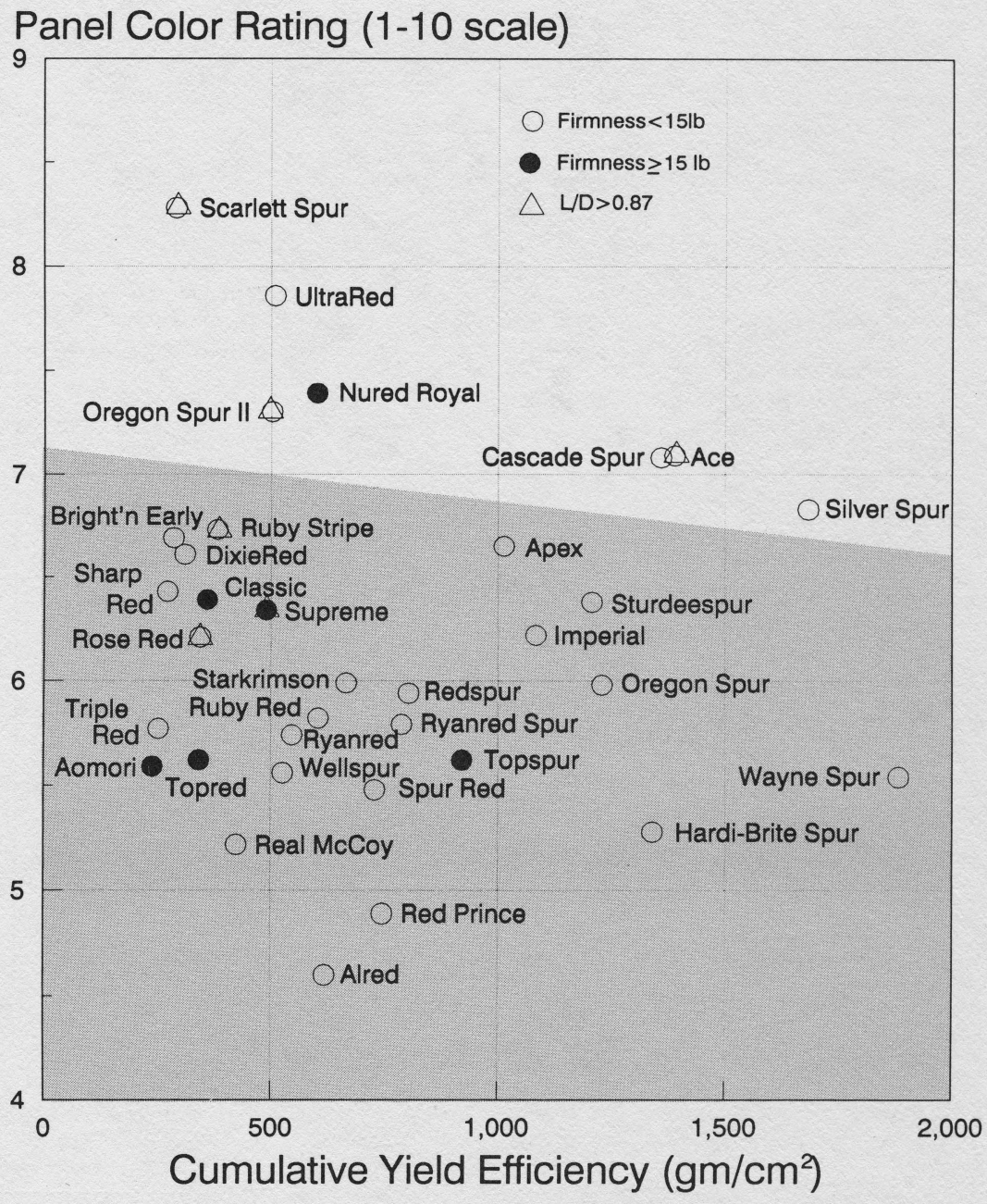




\section{Literature Cited}

Brueggen, J.J., C. Botkin, R. Lewis, C. Mace, A. Wilcox. 1988. West Virginia Fruit Tree Survey - 1987. West Virginia Department of Agriculture and U.S.D.A. 28 pp.

Crassweller, R.M. and R.A. Hollander. 1988. Are there differences in 'Delicious' strains? The Mountaineer Grower 489:4-10.

Crassweller, R.M., J. Walker, and R.L. Shewfelt. 1984. Color evaluation of seventeen strains of 'Delicious'. Fruit Varieties J. 39:21-24.

Dayton, D.F. 1964. Variation in the pattern of red color distribution in the skin of 'Delicious' and 'Starking' bud sport varieties. Proceedings, Am. Soc. Hort. Sci. 84:44-50.

Dennis, F.G., Jr. 1987. Productivity of 28 strains of 'Delicious' apple. Preliminary evaluation in Michigan. HortScience 22:1045 (Abstract).

Dennis, F.G., Jr. 1981. Limiting factors in fruit set of 'Delicious' apple. Acta Hort. 12:119-124.

Ferree, D.C., J.C. Schmid, and C.A. Morrison. 1982. An evaluation over 16 years of 'Delicious' strains and other cultivars on several rootstocks and hardy interstems. Fruit Varieties J. 36:37-45.

Fisher, D.V. and D.O. Ketchie. 1989. Survey of literature on red strains of 'Delicious'. Washington State University Cooperative Extention Bulletin EB1515. 16 pp.

Heinicke, D.R. 1974. High density apple orchards - planning, training, and pruning. Agriculture Handbook No. 458 ARS-USDA. $34 \mathrm{pp}$.

Ingle, M. and M.C. D'Souza. 1989. Fruit characteristics of 'Red Delicious' apple strains during maturation and storage. J. Amer. Soc. Hort. Sci. 114:776-780.

Ingle, M. 1972. Studies on the maturity and storage behavior of 'Red Delicious' budsports. West Virginia Agricultural and Forestry Experiment Station Bull. 609T. 
Ketchie, D.O. 1986. 'Delicious' strain evaluation summary. Proceedings, Washington State Hort. Assoc. pp. 106-114.

Ketchie, D.O. 1984. Flowering, spur formation and limb angles of 'Delicious' apple strains. Fruit Varieties J. 38:150-152.

Ketchie, D.O., J. Ballard, D. Fisher and K. Olsen. 1978. Evaluating strains of 'Red Delicious' and other varieties - a panel. Proceedings, Washington State Hort. Assoc. pp. 64,66,68.

Lord, W.J. 1982. An evaluation of 'Delicious' strains for the size and shape of fruit. Fruit Varieties J. 36:52-53.

Lord, W.J., R.A. Damon, Jr., J.F. Anderson and F.W. Southwick. 1979. Evaluation of 'Delicious' apple strains for fruit color, productivity, tree size and susceptibility to water core. Proceedings, Massachusetts Fruit Growers Assoc. 85:76-83.

Meheriuk, M., D.V. Fisher and K.O. Lapins. 1973. Some morphological and physiological features of several 'Red Delicious' sports. Canadian J. Plant Sci. 51:246-248.

Olsen, K.L. and D.O. Ketchie. 1978. Coloring and dessert quality of red 'Delicious' strains. Proceedings, Washington State Hort. Assoc. pp. 80,82,84.

Priest, K.L. and E.C. Lougheed. 1981. Evaluating apple maturity using the starch-iodine test. Ontario Ministry of Agriculture and Food Fact Sheet 81-125. 4 pp.

Singha, S., T.A. Baugher and E.C. Townsend. 1989. In situ measurement of fruit color development in six red 'Delicious' strains. HortScience 24:219 (Abstract).

Singha, S., T.A. Baugher, E.C. Townsend and M.L. D'Souza. 1990. Chromaticity values, consumer evaluation, and anthocyanin levels in 'Delicious' apples. HortScience 25: in press (Abstract).

Warrington, I.J., D.C. Ferree, J.R. Schupp, F.G. Dennis, Jr., T.A. Baugher. 1989. Spur characteristics of 'Delicious' apple strains. Amer. Soc. Hort. Sci. Program and Abstracts. p. 128 (Abstract). 
Warrington, I.J., D.C. Ferree, J.R. Schupp, F.G. Dennis, Jr., T.A. Baugher. 1990. Strain and rootstock effects on spur characteristics and yield of 'Delicious' apple. J. Amer. Soc. Hort. Sci. (in press).

Westwood, M.N. and A.N. Roberts. 1970. The relationship between trunk cross-sectional area and weight of apple trees. J. Amer. Soc. Hort. Sci. 95:28-30. 
Blank Page in Original Bulletin 


\section{Appendices}


Blank Page in Original Bulletin 


\section{Appendix A. \\ Color ratings of 'Delicious' strains.}

\begin{tabular}{|c|c|c|c|c|c|}
\hline \multirow[b]{2}{*}{ STRAIN } & \multicolumn{5}{|c|}{ Color Rating (1-10 scale) } \\
\hline & 1985 & 1986 & 1987 & 1988 & Mean \\
\hline Ace & 6.3 & 6.7 & 7.4 & 7.9 & 7.1 \\
\hline Alred & 4.4 & NA & 6.0 & 3.4 & 4.6 \\
\hline Aomori & - & 7.1 & 5.0 & 4.7 & 5.6 \\
\hline Apex & 6.5 & 6.1 & 6.4 & 7.7 & 6.7 \\
\hline Bright'n Early & 7.1 & 5.4 & 7.4 & 6.9 & 6.7 \\
\hline Cascade Spur & 5.7 & 6.3 & 7.7 & 8.7 & 7.1 \\
\hline Classic & 7.2 & 5.1 & 7.6 & 5.6 & 6.4 \\
\hline DixieRed & - & 6.2 & 7.2 & 6.4 & 6.6 \\
\hline Hardi-Brite Spur & 5.0 & 4.8 & 5.8 & 5.5 & 5.3 \\
\hline Imperial & 5.7 & 6.8 & 5.9 & 6.5 & 6.2 \\
\hline Nured Royal & 6.9 & 7.7 & 7.9 & 7.1 & 7.4 \\
\hline Oregon Spur & 5.2 & 6.1 & 6.0 & 6.6 & 6.0 \\
\hline Oregon Spur II & 5.6 & 7.1 & 7.3 & 9.1 & 7.3 \\
\hline Real McCoy & - & 5.3 & 5.2 & 5.2 & 5.2 \\
\hline Red Prince & 5.7 & 3.3 & 5.1 & 5.4 & 4.9 \\
\hline Redchief(Campbell) & 6.6 & 7.9 & 8.1 & 7.5 & 7.5 \\
\hline Redspur & 6.1 & 5.9 & 5.8 & 5.9 & 5.9 \\
\hline Rose Red & - & 5.9 & 6.7 & 6.0 & 6.2 \\
\hline Ruby Red & 4.4 & 5.6 & 6.7 & 6.6 & 5.8 \\
\hline Ruby Stripe & 6.5 & 5.9 & 7.2 & 7.3 & 6.7 \\
\hline Ryanred & 5.7 & 6.7 & 5.3 & 5.3 & 5.7 \\
\hline Ryanred Spur & 5.5 & 5.5 & 5.8 & 6.3 & 5.8 \\
\hline Scarlett Spur & 8.9 & 7.5 & 7.9 & 8.8 & 8.3 \\
\hline Sharp Red & - & 6.9 & 6.8 & 5.6 & 6.4 \\
\hline silver Spur & 6.1 & 6.9 & 8.3 & 6.0 & 6.8 \\
\hline Spur Red & 4.1 & NA & 6.3 & 6.1 & 5.5 \\
\hline starkrimson & 6.7 & 4.9 & 6.8 & 5.6 & 6.0 \\
\hline Sturdeespur & 5.1 & 6.6 & 7.2 & 6.6 & 6.4 \\
\hline Supreme & 7.7 & 6.9 & 6.8 & 4.0 & 6.3 \\
\hline Topred & 6.6 & 5.7 & 5.2 & 5.0 & 5.6 \\
\hline Topspur & 5.3 & 7.0 & 5.5 & 4.6 & 5.6 \\
\hline Triple Red & - & NA & 5.8 & 5.7 & 5.8 \\
\hline UltraRed & 7.1 & 8.4 & 8.2 & 7.7 & 7.9 \\
\hline UltraStripe & - & 8.8 & 8.6 & 8.5 & 8.6 \\
\hline Wayne Spur & 4.5 & 5.9 & 5.5 & 6.2 & 5.5 \\
\hline Wellspur & 5.1 & 5.9 & 5.8 & 5.4 & 5.6 \\
\hline LSD $(p=0.05)$ & 2.8 & 2.5 & 2.2 & 2.3 & 1.7 \\
\hline
\end{tabular}


Blank Page in Original Bulletin 


\section{Appendix B-1. TCSA of 'Delicious' strains.}

\begin{tabular}{|c|c|c|c|c|c|c|c|}
\hline & \multicolumn{7}{|c|}{$\operatorname{TCSA}\left(\mathrm{cm}^{2}\right)$} \\
\hline $\begin{array}{l}\text { STRAIN } \\
\text { Ace }\end{array}$ & $\begin{array}{r}1982 \\
1.3\end{array}$ & $\begin{array}{r}1985 \\
3.1\end{array}$ & $\begin{array}{r}1984 \\
5.0\end{array}$ & $\begin{array}{r}1985 \\
9.0\end{array}$ & $\begin{array}{l}1980 \\
15.3\end{array}$ & 20.1 & $\begin{array}{l}1900 \\
31.7\end{array}$ \\
\hline Alred & 0.9 & 2.5 & 4.8 & 11.5 & 22.8 & 35.2 & 58.2 \\
\hline Aomor $\mathrm{i}$ & 1.5 & 2.4 & 5.1 & 12.7 & 24.7 & 41.6 & 68.0 \\
\hline Apex & 0.5 & 2.2 & 4.4 & 9.9 & 17.4 & 23.1 & 35.8 \\
\hline Bright'n Early & 0.8 & 2.3 & 5.1 & 12.5 & 22.0 & 36.5 & 49.4 \\
\hline Cascade Spur & 1.4 & 2.1 & 4.5 & 10.3 & 15.9 & 26.9 & 36.8 \\
\hline Classic & 1.3 & 4.2 & 7.9 & 17.4 & 30.2 & 43.0 & 66.4 \\
\hline DixieRed & 1.2 & 1.6 & 3.4 & 9.5 & 18.7 & 32.5 & 54.4 \\
\hline Hardi-Brite Spur & 1.2 & 3.6 & 5.8 & 13.6 & 21.3 & 26.8 & 42.8 \\
\hline Imperial & 1.1 & 3.8 & 6.8 & 15.0 & 26.3 & 37.2 & 54.8 \\
\hline Nured Royal & 1.2 & 3.7 & 6.6 & 14.6 & 26.5 & 38.0 & 60.4 \\
\hline Oregon Spur & 1.6 & 3.9 & 6.6 & 15.0 & 26.0 & 37.5 & 55.9 \\
\hline Oregon Spur II & 1.4 & 3.8 & 7.6 & 18.8 & 32.3 & 52.2 & 72.7 \\
\hline Real McCoy & 1.5 & 2.2 & 4.9 & 12.7 & 21.9 & 37.0 & 60.1 \\
\hline Red Prince & 1.3 & 3.8 & 7.6 & 16.1 & 31.7 & 42.9 & 60.2 \\
\hline Redspur & 1.3 & 3.1 & 5.5 & 12.2 & 21.1 & 27.6 & 42.7 \\
\hline Rose Red & 1.4 & 3.0 & 5.4 & 12.2 & 22.2 & 35.6 & 57.7 \\
\hline Ruby Red & 1.0 & 2.4 & 4.2 & 11.2 & 20.0 & 30.8 & 45.5 \\
\hline Ruby Stripe & 1.4 & 2.8 & 5.4 & 13.4 & 24.0 & 35.8 & 56.9 \\
\hline Ryanred & 1.1 & 3.3 & 5.9 & 13.0 & 22.5 & 36.7 & 53.3 \\
\hline Ryanred Spur & 1.3 & 2.7 & 4.2 & 9.7 & 17.8 & 27.1 & 41.1 \\
\hline Scarlett Spur & 2.3 & 3.9 & 7.7 & 16.6 & 29.7 & 42.9 & 59.9 \\
\hline Sharp Red & 2.8 & 4.5 & 7.8 & 16.0 & 29.8 & 40.0 & 64.3 \\
\hline silver spur & 0.6 & 2.2 & 4.6 & 10.1 & 19.6 & 28.1 & 38.4 \\
\hline Spur Red & 0.6 & 2.6 & 5.0 & 12.1 & 18.8 & 27.3 & 39.2 \\
\hline starkrimson & 1.5 & 2.4 & 5.2 & 12.4 & 22.5 & 36.0 & 51.7 \\
\hline Sturdeespur & 1.0 & 2.8 & 4.8 & 9.4 & 18.3 & 23.2 & 34.3 \\
\hline Supreme & 1.4 & 2.2 & 4.5 & 10.4 & 20.5 & 30.6 & 48.7 \\
\hline Topred & 1.5 & 3.6 & 7.1 & 16.6 & 30.5 & 43.2 & 68.5 \\
\hline Topspur & 1.1 & 3.0 & 4.7 & 9.3 & 15.1 & 19.1 & 28.2 \\
\hline Triple Red & 0.8 & 2.9 & 6.2 & 13.6 & 25.1 & 35.7 & 61.6 \\
\hline UltraRed & 1.2 & 1.6 & 3.5 & 8.9 & 16.9 & 29.0 & 39.4 \\
\hline Wayne Spur & 0.6 & 2.7 & 5.8 & 11.2 & 20.2 & 26.5 & 35.8 \\
\hline Well lspur & 2.2 & 5.3 & 9.0 & 15.9 & 26.8 & 33.1 & 55.6 \\
\hline LSD $(p=0.05)$ & 0.3 & 0.9 & 2.1 & 5.2 & 8.9 & 12.4 & 16.1 \\
\hline
\end{tabular}


Appendix B-2.

Yields of 'Delicious' strains.

$\begin{array}{lrrrrr}\text { STRAIN } & 1985 & 1986 & 1987 & 1988 & \text { Total } \\ \text { Ace } & & & & & \\ \text { Alred } & 3.3 & 18.1 & 8.8 & 13.4 & 43.6 \\ \text { Aomori } & 0.8 & 11.0 & 9.8 & 17.1 & 38.7 \\ \text { Apex } & 0.0 & 5.7 & 5.8 & 5.5 & 17.0 \\ \text { Bright'n Early } & 1.9 & 12.4 & 9.0 & 12.6 & 35.9 \\ \text { Cascade Spur } & 0.1 & 4.8 & 3.0 & 7.4 & 15.3 \\ \text { Classic } & 3.6 & 17.7 & 7.3 & 22.0 & 50.6 \\ \text { DixieRed } & 0.1 & 11.4 & 4.0 & 8.2 & 23.7 \\ \text { Hardi-Brite Spur } & 0.0 & 4.3 & 3.7 & 8.2 & 16.2 \\ \text { Imperial } & 2.9 & 25.3 & 8.2 & 22.2 & 58.6 \\ \text { Nured Royal } & 1.2 & 22.4 & 16.9 & 19.7 & 60.2 \\ \text { Oregon Spur } & 0.2 & 11.5 & 6.8 & 17.6 & 36.1 \\ \text { Oregon Spur } 11 & 1.1 & 23.0 & 17.2 & 26.7 & 68.0 \\ \text { Real McCoy } & 0.9 & 10.5 & 9.2 & 15.7 & 36.3 \\ \text { Red Prince } & 0.0 & 5.6 & 6.2 & 13.4 & 25.2 \\ \text { Redspur } & 0.4 & 12.4 & 14.5 & 18.0 & 45.3 \\ \text { Rose Red } & 1.3 & 19.1 & 5.7 & 8.6 & 34.7 \\ \text { Ruby Red } & 0.0 & 10.5 & 3.5 & 5.1 & 19.1 \\ \text { Ruby Stripe } & 0.6 & 9.1 & 7.5 & 11.4 & 28.6 \\ \text { Ryanred } & 0.3 & 5.7 & 4.6 & 10.5 & 21.1 \\ \text { Ryanred Spur } & 0.4 & 15.7 & 4.4 & 8.2 & 28.7 \\ \text { Scarlett Spur } & 0.7 & 13.8 & 4.8 & 12.6 & 31.2 \\ \text { Sharp Red } & 0.1 & 6.7 & 4.7 & 5.9 & 17.4 \\ \text { Silver Spur } & 0.0 & 4.8 & 4.1 & 8.3 & 17.2 \\ \text { Spur Red } & 0.7 & 22.3 & 15.7 & 23.6 & 62.3 \\ \text { Starkrimson } & 0.5 & 11.0 & 6.4 & 11.0 & 28.9 \\ \text { Sturdeespur } & 0.4 & 4.8 & 7.7 & 21.4 & 34.3 \\ \text { Supreme } & 1.9 & 20.2 & 7.0 & 11.4 & 40.5 \\ \text { Topred } & 0.3 & 9.1 & 9.3 & 8.6 & 26.3 \\ \text { Topspur } & 0.2 & 8.1 & 6.5 & 8.1 & 22.9 \\ \text { Triple Red } & 1.4 & 11.9 & 4.1 & 4.0 & 21.4 \\ \text { UltraRed } & 0.0 & 7.6 & 2.4 & 5.4 & 15.4 \\ \text { Wayne Spur } & 0.4 & 8.1 & 3.3 & 8.0 & 19.8 \\ \text { Wellspur } & 3.4 & 23.4 & 16.3 & 23.7 & 66.8 \\ & 0.9 & 12.4 & 4.3 & 10.1 & 27.7 \\ \text { LSD (p = 0.05) } & 1.6 & 8.6 & 9.0 & 10.2 & 25.2 \\ & & & & & \\ & & & & & \\ & & & & & \end{array}$




\section{Appendix B-3.}

Yield efficiency of 'Delicious' strains.

\begin{tabular}{|c|c|c|c|c|c|}
\hline \multirow[b]{2}{*}{ STRAIN } & \multicolumn{5}{|c|}{ Yield Efficiency $\left(\mathrm{gm} / \mathrm{cm}^{2}\right)$} \\
\hline & 1985 & 1986 & 1987 & 1988 & Mean \\
\hline Ace & 393 & 1208 & 439 & 427 & 617 \\
\hline Alred & 56 & 463 & 260 & 270 & 262 \\
\hline Aomori & 0 & 219 & 129 & 80 & 107 \\
\hline Apex & 197 & 714 & 401 & 354 & 417 \\
\hline Bright'n Early & 12 & 214 & $\sqrt{5}$ & 132 & 108 \\
\hline Cascade Spur & 344 & 1107 & 305 & 596 & 588 \\
\hline Classic & 9 & 383 & 91 & 123 & 152 \\
\hline DixieRed & 0 & 248 & 119 & 157 & 131 \\
\hline Hardi-Brite Spur & 190 & 1158 & 308 & 508 & 541 \\
\hline Imperial & 78 & 821 & 432 & 358 & 422 \\
\hline Nured Royal & 13 & 439 & 180 & 294 & 232 \\
\hline Oregon Spur & 75 & 896 & 464 & 483 & 479 \\
\hline Oregon Spur II & 48 & 327 & 177 & 218 & 192 \\
\hline Real McCoy & 0 & 257 & 177 & 224 & 165 \\
\hline Red Prince & 25 & 375 & 322 & 298 & 255 \\
\hline Redspur & 101 & 899 & 201 & 200 & 350 \\
\hline Rose Red & 0 & 497 & 102 & 92 & 173 \\
\hline Ruby Red & 45 & 441 & 228 & 242 & 239 \\
\hline Ruby Stripe & 20 & 237 & 133 & 187 & 144 \\
\hline Ryanred & 33 & 705 & 120 & 156 & 254 \\
\hline Ryanred Spur & 72 & 783 & 180 & 313 & 337 \\
\hline Scarlett Spur & 6 & 235 & 114 & 97 & 113 \\
\hline Sharp Red & 0 & 162 & 104 & 131 & 99 \\
\hline silver spur & $\pi$ & 1181 & 565 & 641 & 616 \\
\hline Spur Red & 44 & 578 & 241 & 273 & 284 \\
\hline Starkrimson & 31 & 212 & 214 & 416 & 218 \\
\hline Sturdeespur & 203 & 1130 & 301 & 338 & 493 \\
\hline Supreme & 24 & 394 & 258 & 152 & 207 \\
\hline Topred & 12 & 268 & 154 & 121 & 139 \\
\hline Topspur & 173 & 928 & 229 & 161 & 373 \\
\hline Triple Red & 0 & 311 & 68 & 88 & 117 \\
\hline UltraRed & 37 & 476 & 115 & 207 & 209 \\
\hline Wayne Spur & 294 & 1161 & 630 & 671 & 689 \\
\hline Well lspur & 58 & 472 & 136 & 191 & 214 \\
\hline LSD $(p=0.05)$ & 138 & 336 & 231 & 160 & 160 \\
\hline
\end{tabular}


Blank Page in Original Bulletin 


\section{Appendix C-1.}

\section{Length/diameter ratios of 'Delicious' strains.}

\begin{tabular}{lccccc} 
& & \multicolumn{4}{c}{ L/D Ratio } \\
STRAIN & 1985 & 1986 & 1987 & 1988 & Mean \\
Ace & & & & & \\
Alred & 0.83 & 0.88 & 0.87 & 0.90 & 0.87 \\
Aomori & 0.82 & 0.85 & 0.84 & 0.85 & 0.84 \\
Apex & - & 0.86 & 0.84 & 0.86 & 0.85 \\
Bright'n Early & 0.84 & 0.83 & 0.87 & 0.88 & 0.86 \\
Cascade Spur & - & 0.86 & 0.85 & 0.88 & 0.86 \\
Classic & 0.82 & 0.87 & 0.87 & 0.89 & 0.86 \\
DixieRed & - & 0.86 & 0.84 & 0.85 & 0.85 \\
Hardi-Brite Spur & 0.80 & 0.85 & 0.85 & 0.85 & 0.85 \\
Imperial & 0.85 & 0.84 & 0.88 & 0.85 & 0.84 \\
Nured Royal & - & 0.88 & 0.85 & 0.92 & 0.86 \\
Oregon Spur & 0.78 & 0.84 & 0.86 & 0.89 & 0.86 \\
Oregon Spur 11 & 0.83 & 0.87 & 0.90 & 0.87 & 0.85 \\
Real McCoy & - & 0.82 & 0.86 & 0.83 & 0.84 \\
Red Prince & 0.85 & 0.85 & 0.87 & 0.86 & 0.86 \\
Redspur & 0.83 & 0.86 & 0.88 & 0.88 & 0.86 \\
Rose Red & - & 0.86 & 0.87 & 0.88 & 0.87 \\
Ruby Red & 0.82 & 0.87 & 0.90 & 0.88 & 0.86 \\
Ruby Stripe & 0.84 & 0.87 & 0.89 & 0.89 & 0.88 \\
Ryanred & 0.80 & 0.82 & 0.83 & 0.86 & 0.83 \\
Ryanred Spur & 0.80 & 0.85 & 0.84 & 0.88 & 0.84 \\
Scarlett Spur & - & 0.86 & 0.91 & 0.84 & 0.87 \\
Sharp Red & - & 0.85 & 0.84 & 0.85 & 0.85 \\
Silver Spur & 0.81 & 0.85 & 0.88 & 0.91 & 0.86 \\
Spur Red & 0.85 & 0.87 & 0.90 & 0.90 & 0.88 \\
Starkrimson & 0.86 & 0.86 & 0.88 & 0.86 & 0.86 \\
Sturdeespur & 0.84 & 0.83 & 0.90 & 0.86 & 0.86 \\
Supreme & 0.84 & 0.88 & 0.94 & 0.92 & 0.90 \\
Topred & - & 0.86 & 0.85 & 0.87 & 0.86 \\
Topspur & 0.84 & 0.85 & 0.86 & 0.86 & 0.85 \\
Triple Red & - & 0.84 & NA & 0.86 & 0.85 \\
UltraRed & 0.83 & 0.84 & 0.86 & 0.87 & 0.85 \\
Wayne Spur & 0.81 & 0.84 & 0.91 & 0.89 & 0.86 \\
Wellspur & 0.83 & 0.85 & 0.87 & 0.87 & 0.86 \\
& & & & & \\
LSD (p = 0.05) & 0.03 & 0.04 & 0.04 & 0.05 & 0.02 \\
& & & & & \\
& & & & &
\end{tabular}




\section{Appendix C-2. \\ Fruit diameter of 'Delicious' strains.}

\begin{tabular}{|c|c|c|c|c|c|}
\hline STRAIN & 1985 & $\begin{array}{l}\text { Fruit } \\
1986\end{array}$ & $\begin{array}{c}\text { Diamete } \\
1987\end{array}$ & $\begin{array}{r}r(\mathrm{~cm}) \\
1988\end{array}$ & Mean \\
\hline Ace & 8.7 & 7.7 & 8.1 & 7.5 & 8.0 \\
\hline Alred & 8.4 & 7.7 & 8.2 & 8.0 & 8.1 \\
\hline Aomori & - & 8.2 & 8.2 & 7.9 & 8.1 \\
\hline Apex & 8.1 & 7.8 & 7.8 & 7.6 & 7.8 \\
\hline Bright'n Early & - & 7.6 & 7.9 & 7.9 & 7.8 \\
\hline Cascade Spur & 8.6 & 8.0 & 8.3 & 7.5 & 8.1 \\
\hline Classic & - & 7.8 & 7.9 & 7.5 & 7.7 \\
\hline DixieRed & - & 8.0 & 7.8 & 8.0 & 7.9 \\
\hline Hardi-Brite Spur & 8.6 & 7.8 & 7.7 & 7.9 & 8.0 \\
\hline Imperial & 8.4 & 8.1 & 8.3 & 7.9 & 8.2 \\
\hline Nured Royal & - & 8.0 & 8.1 & 7.6 & 7.9 \\
\hline Oregon Spur & 8.8 & 8.3 & 8.0 & 7.9 & 8.3 \\
\hline Oregon Spur II & 8.4 & 7.7 & 7.8 & 7.7 & 7.9 \\
\hline Real McCoy & - & 8.2 & 8.2 & 8.0 & 8.1 \\
\hline Red Prince & 8.1 & 8.0 & 7.8 & 7.9 & 7.9 \\
\hline Redspur & 8.5 & 7.8 & 7.9 & 7.6 & 8.0 \\
\hline Rose Red & - & 7.9 & 8.1 & 7.9 & 8.0 \\
\hline Ruby Red & 7.7 & 7.3 & 7.4 & 7.4 & 7.5 \\
\hline Ruby Stripe & 7.6 & 7.9 & 7.8 & 7.4 & 7.7 \\
\hline Ryanred & 8.4 & 7.7 & 8.0 & 7.7 & 7.9 \\
\hline Ryanred Spur & 8.6 & 7.9 & 8.1 & 7.7 & 8.1 \\
\hline Scarlett Spur & - & 7.8 & 7.8 & 7.7 & 7.8 \\
\hline Sharp Red & - & 8.2 & 8.2 & 8.0 & 8.1 \\
\hline silver spur & 8.9 & 7.9 & 8.0 & 8.0 & 8.2 \\
\hline Spur Red & 8.1 & 7.4 & 7.6 & 7.7 & 7.7 \\
\hline Starkrimson & 8.6 & 7.6 & 7.8 & 7.9 & 7.9 \\
\hline Sturdeespur & 8.3 & 7.5 & 7.6 & 7.9 & 7.8 \\
\hline Supreme & 8.8 & 7.8 & 8.1 & 7.7 & 8.0 \\
\hline Topred & - & 7.8 & 7.9 & 7.5 & 7.7 \\
\hline Topspur & 8.2 & 7.5 & 7.5 & 7.4 & 7.7 \\
\hline Triple Red & - & 7.5 & NA & 7.5 & 7.5 \\
\hline UltraRed & 8.6 & 8.2 & 7.8 & 7.7 & 8.0 \\
\hline Wayne Spur & 8.6 & 7.8 & 7.6 & 7.7 & 7.9 \\
\hline Well spur & 8.0 & 7.6 & 7.5 & 7.7 & 7.7 \\
\hline $\operatorname{LSD}(p=0.05)$ & 0.4 & 0.4 & 0.5 & 0.5 & 0.3 \\
\hline
\end{tabular}




\section{Appendix D-1.}

Fruit firmness of 'Delicious' strains.

\section{STRAIN}

Ace

Alred

Aomor i

Apex

Bright'n Early

Cascade Spur

Classic

DixieRed

Hardi-Brite Spur

Imperial

Nured Royal

Oregon Spur

Oregon Spur II

Real McCoy

Red Prince

Redspur

Rose Red

Ruby Red

Ruby Stripe

Ryanred

Ryanred Spur

Scarlett Spur

Sharp Red

Silver Spur

Spur Red

Starkrimson

Sturdeespur

Supreme

Topred

Topspur

Triple Red

UltraRed

Wayne Spur

Well lspur

LSD $(p=0.05)$
Firmness (lbs)

$\begin{array}{lllll}1985 & 1986 \quad 1987 \quad 1988 \text { Mean }\end{array}$

$\begin{array}{lllll}13.2 & 15.8 & 14.7 & 13.7 & 14.4\end{array}$

$\begin{array}{lllll}14.6 & 15.1 & 15.2 & 13.6 & 14.6\end{array}$

$\begin{array}{lllll}- & 15.9 & 15.2 & 14.1 & 15.1\end{array}$

$\begin{array}{lllll}14.6 & 15.6 & 15.4 & 14.1 & 15.0\end{array}$

$\begin{array}{lllll}- & 15.0 & 15.3 & 13.6 & 14.6\end{array}$

$\begin{array}{lllll}13.3 & 15.0 & 14.5 & 13.7 & 14.1\end{array}$

$\begin{array}{lllll}- & 16.2 & 15.6 & 14.4 & 15.4\end{array}$

$\begin{array}{lllll}- & 15.2 & 14.3 & 13.0 & 14.2\end{array}$

$\begin{array}{lllll}13.7 & 15.6 & 15.0 & 14.1 & 14.6\end{array}$

$\begin{array}{lllll}13.3 & 14.2 & 15.0 & 13.2 & 13.9\end{array}$

$\begin{array}{lllll}- & 15.7 & 16.0 & 13.8 & 15.2\end{array}$

$\begin{array}{lllll}14.8 & 15.2 & 15.4 & 13.8 & 14.8\end{array}$

$\begin{array}{lllll}13.5 & 14.8 & 15.2 & 13.6 & 14.3\end{array}$

$\begin{array}{lllll}- & 14.6 & 14.5 & 13.3 & 14.1\end{array}$

$\begin{array}{lllll}14.2 & 14.8 & 15.8 & 14.0 & 14.8\end{array}$

$\begin{array}{lllll}12.6 & 14.6 & 14.8 & 13.4 & 13.8\end{array}$

$\begin{array}{lllll}- & 15.4 & 14.7 & 13.5 & 14.5\end{array}$

$\begin{array}{lllll}13.6 & 15.8 & 15.8 & 14.2 & 14.9\end{array}$

$\begin{array}{lllll}15.3 & 14.8 & 15.2 & 13.7 & 14.7\end{array}$

$\begin{array}{lllll}14.0 & 14.8 & 15.0 & 13.2 & 14.3\end{array}$

$\begin{array}{lllll}13.1 & 15.6 & 14.9 & 13.9 & 14.4\end{array}$

$\begin{array}{lllll}- & 15.5 & 14.8 & 13.4 & 14.6\end{array}$

$\begin{array}{lllll}- & 14.7 & 14.7 & 13.9 & 14.5\end{array}$

$\begin{array}{lllll}13.4 & 15.0 & 14.3 & 13.7 & 14.1\end{array}$

$\begin{array}{lllll}14.0 & 14.7 & 15.8 & 13.6 & 14.5\end{array}$

$\begin{array}{lllll}12.3 & 16.0 & 15.2 & 13.6 & 14.6\end{array}$

$\begin{array}{lllll}13.5 & 15.0 & 15.5 & 12.7 & 14.2\end{array}$

$\begin{array}{lllll}15.0 & 16.1 & 15.8 & 14.8 & 15.5\end{array}$

$\begin{array}{lllll}- & 15.5 & 16.1 & 14.4 & 15.4\end{array}$

$\begin{array}{lllll}14.2 & 15.5 & 16.2 & 14.7 & 15.1\end{array}$

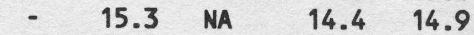

$\begin{array}{lllll}13.5 & 14.0 & 15.5 & 13.6 & 14.3\end{array}$

$\begin{array}{lllll}13.5 & 15.4 & 15.5 & 14.3 & 14.7\end{array}$

$\begin{array}{lllll}14.2 & 15.1 & 15.7 & 13.9 & 14.7\end{array}$

$\begin{array}{lllll}1.8 & 0.9 & 1.3 & 1.1 & 0.7\end{array}$ 


\section{Appendix D-2. \\ Soluble solids of 'Delicious' strains.}

\begin{tabular}{lccccc} 
STRAIN & 1985 & 1986 & 1987 & 1988 & Mean \\
Ace & & & & & \\
Alred & 14.4 & 12.0 & 14.5 & 13.3 & 13.5 \\
Aomori & 15.1 & 13.8 & 14.6 & 13.5 & 14.3 \\
Apex & - & 14.0 & 15.5 & 13.9 & 14.5 \\
Bright'n Early & 14.5 & 12.3 & 14.0 & 13.3 & 13.5 \\
Cascade Spur & - & 13.0 & 14.7 & 13.5 & 13.7 \\
Classic & 14.9 & 12.7 & 14.5 & 13.6 & 13.9 \\
DixieRed & - & 13.6 & 15.1 & 13.7 & 14.1 \\
Hardi-Brite Spur & 14.7 & 13.1 & 13.5 & 13.0 & 13.2 \\
Imperial & 15.7 & 14.3 & 13.5 & 13.3 & 13.5 \\
Nured Royal & - & 14.3 & 15.3 & 14.3 & 15.1 \\
Oregon Spur & 13.5 & 12.3 & 13.3 & 12.5 & 15.0 \\
Oregon Spur 11 & 13.1 & 12.9 & 13.3 & 12.9 & 13.9 \\
Real McCoy & - & 15.0 & 15.1 & 15.4 & 15.1 \\
Red Prince & 14.8 & 15.2 & 15.8 & 13.9 & 14.9 \\
Redspur & 15.0 & 11.4 & 14.4 & 12.4 & 13.3 \\
Rose Red & - & 13.9 & 15.5 & 13.4 & 14.3 \\
Ruby Red & 13.2 & 12.2 & 13.5 & 12.2 & 12.8 \\
Ruby Stripe & 13.5 & 12.1 & 13.5 & 12.1 & 12.7 \\
Ryanred & 15.8 & 13.9 & 15.6 & 14.3 & 14.9 \\
Ryanred Spur & 14.8 & 13.1 & 14.7 & 14.6 & 14.3 \\
Scarlett Spur & - & 11.9 & 13.5 & 12.2 & 12.5 \\
Sharp Red & - & 15.0 & 16.0 & 15.9 & 15.7 \\
Silver Spur & 13.7 & 12.9 & 13.8 & 12.9 & 13.3 \\
Spur Red & 13.3 & 12.6 & 13.5 & 12.4 & 13.0 \\
Starkrimson & 15.3 & 13.0 & 14.4 & 13.6 & 13.9 \\
Sturdeespur & 14.2 & 12.6 & 14.3 & 13.8 & 13.7 \\
Supreme & 14.0 & 13.2 & 14.7 & 13.2 & 13.8 \\
Topred & - & 14.4 & 15.8 & 13.8 & 14.7 \\
Topspur & 15.1 & 13.0 & 15.5 & 13.9 & 14.4 \\
Triple Red & - & 13.9 & NA & 13.9 & 13.9 \\
UltraRed & 14.6 & 13.2 & 13.2 & 13.7 & 13.6 \\
Wayne Spur & 13.9 & 12.5 & 13.8 & 13.1 & 13.3 \\
Wellspur & 14.6 & 14.1 & 14.2 & 14.0 & 14.2 \\
& & & & & \\
LSD (p = 0.05) & 1.8 & 1.4 & 1.1 & 1.3 & 0.8 \\
& & & & & \\
\hline & & & & &
\end{tabular}




\section{Appendix D-3.}

Starch indexes of 'Delicious' strains.

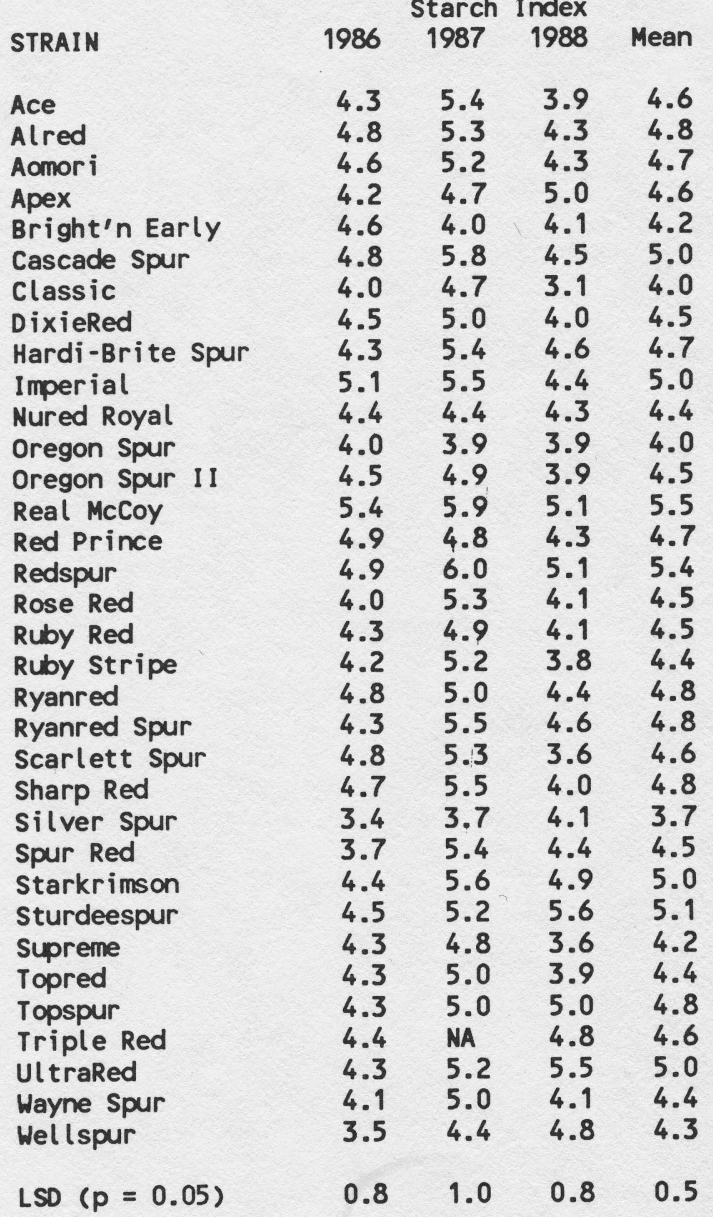




\section{Blank Page in Original Bulletin}




\section{Blank Page in Original Bulletin}


$24-6 y^{2}=$ -1.2

$+1$

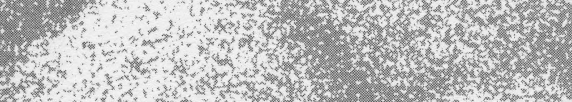

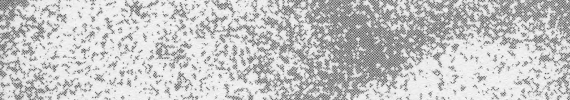

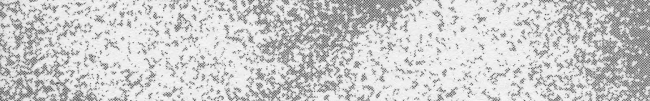

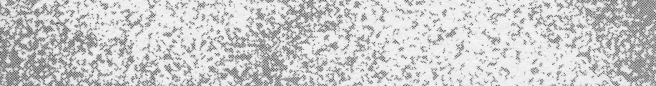
(1)

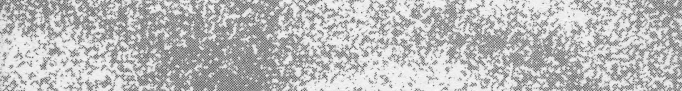
ard (3)

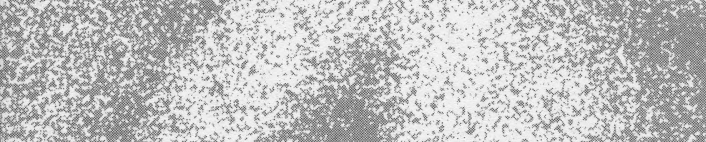

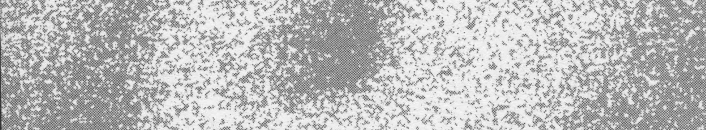
15x

1.2. 1.2. 2.t.

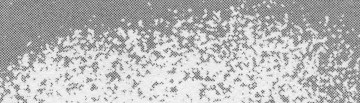

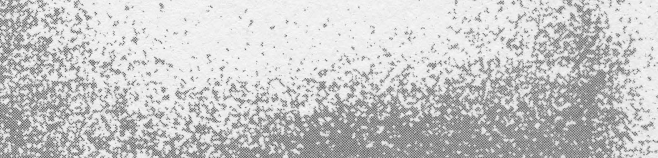

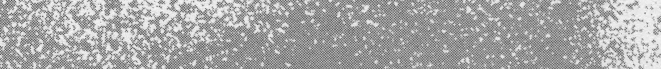

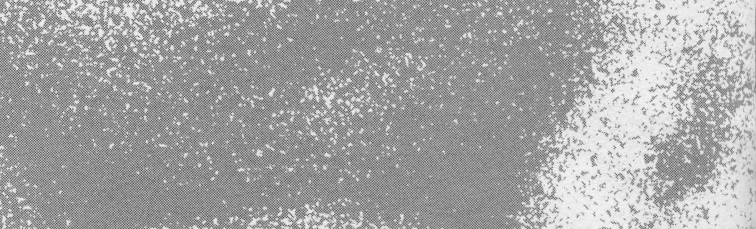

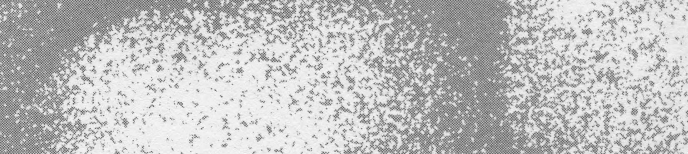

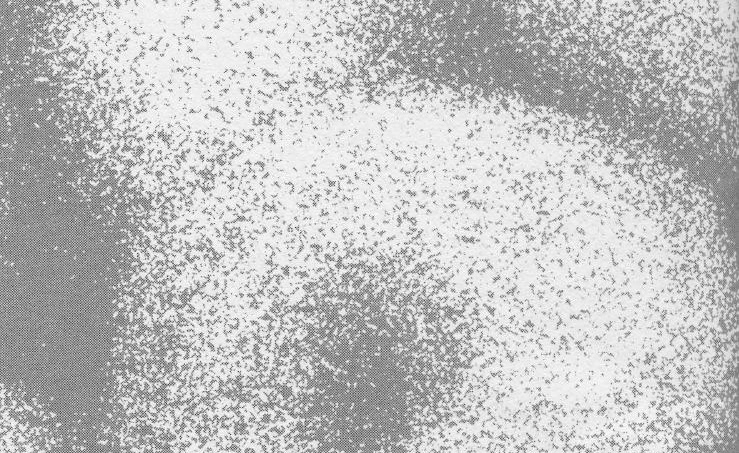

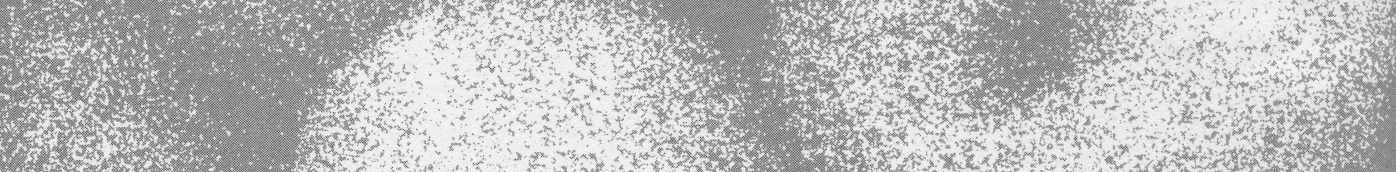

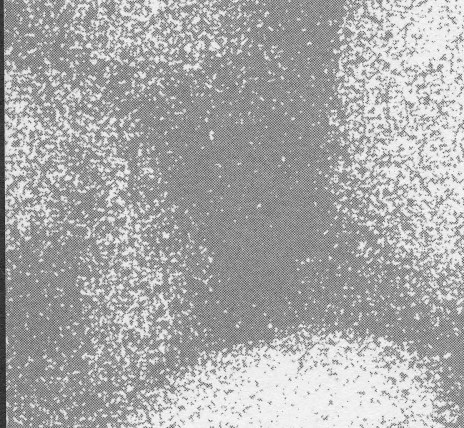
25: $3 \geqslant$.

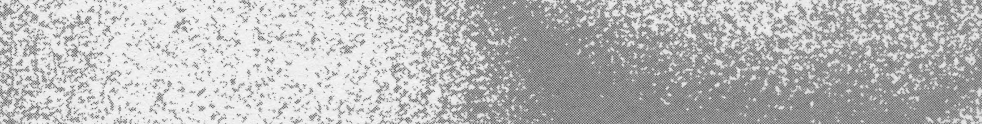

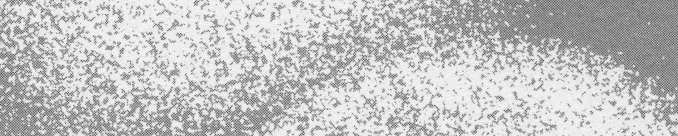
-2.

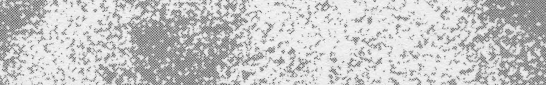

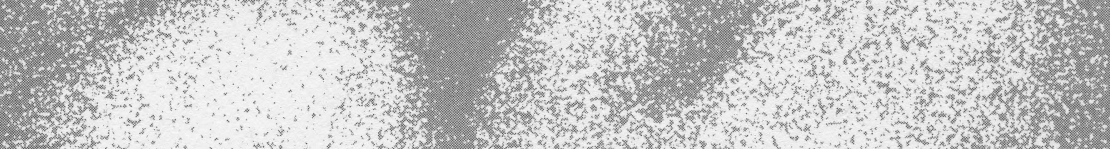
18.

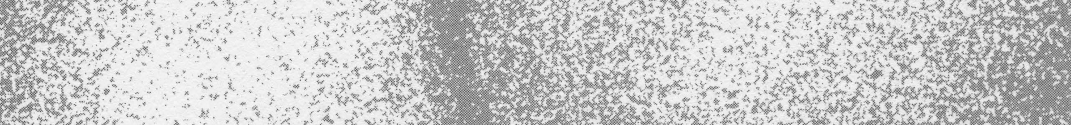
8.7.

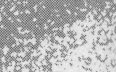
ift: (3) 